\section{B A Institute of \\ YK Business Administration \\ 六下 \\ Karachi \\ Leadership and Ideas for Tomorrow}

\section{Business Review}

\author{
Volume 15 Issue 2
} July-December 2020

$1-15-2021$

\title{
Extreme tails behavior in Asian currency markets
}

Sumaira Zia

Capital University of Science and Technology, Islamabad, Pakistan

Arshad Hassan

Capital University of Science and Technology, Islamabad, Pakistan

Ayesha Zia

Capital University of Science and Technology, Islamabad, Pakistan

Follow this and additional works at: https://ir.iba.edu.pk/businessreview

Part of the Finance Commons

(c) (i)

This work is licensed under a Creative Commons Attribution 4.0 International License.

\section{Recommended Citation}

Zia, S., Hassan, A., \& Zia, A. (2021). Extreme tails behavior in Asian currency markets. Business Review, 15(2), 101-115. Retrieved from https://doi.org/10.54784/1990-6587.1063

This article is brought to you by iRepository for open access under the Creative Commons Attribution 4.0 License and is available at https://ir.iba.edu.pk/businessreview/vol15/iss2/6. For more information, please contact irepository@iba.edu.pk. 


\title{
Design perception and consumer-brand relationship in textile apparel: Mediating role of experiential value and moderating role of openness to experience
}

\author{
Rohail Jibran • \\ Muhammad Ahmad ur Rehman . \\ Sadia Shaheen
}

\begin{abstract}
Pakistan's fashion and apparel market has shown comprehensive growth during the last decade. This paper aims to investigate the impact of design perception on consumer based brand equity and examines the mediating role of experiential value and moderating role of openness to experience. Data was collected from 210 consumers of textile apparel brands in Pakistan. Findings of the study reveal that there is a significant relationship between design perception and consumer based brand equity, experiential value mediates the relationship between design perception and consumer based brand equity. Furthermore results reveal that the personality trait of openness to experience plays a moderating role between the relationship of design perception and experiential value. This framework will encourage marketers and managers to adopt design thinking strategy, that will help to generate greater pleasure and social experiential value from product usage.
\end{abstract}

Keywords Design perception - Experiential value · Consumer based brand equity $\cdot$ Openness to experience

\section{Introduction}

Apparel industry is characterized by stiff competition, therefore to strengthen the consumer-brand relationship, brands have focused on providing a thrilling experience to customers through design (Brakus et al 2014). Many product development characteristics have been studied in marketing literature but product design has received only fragmented attention (Kumar and Noble 2016). Design

Rohail Jibran

National Textile University-Pakistan

Muhammad Ahmad ur Rehman

National Textile University-Pakistan

E-mail: mahmadurrehman@gmail.com

Sadia Shaheen

Lyallpur Business School-Pakistan

(C)Jibran, R., Rehman, A. M. and Shaheen, S. 2020 
perception plays an important role in consumer-brand relationship because a good design creates a positive perception of the brand which increases brand equity (Mishra et al 2015b). Product design is a very important factor in different aspects of marketing like competitive advantage against the competing brands in the marketplace (Jung et al 2014) and making effect and impression on the consumers (Sheng and Teo 2012).

Pakistan's fashion and apparel market growth is increasing rapidly day by day (Dawn 2017) and brands are trying to appoint top fashion designers to design their range of products because they need to make those designs which are novel, attractive and helps them to generate positive perception in the mind of consumers (Homburg et al 2015). In Pakistan, apparel brands are getting more and more attractive and have shown comprehensive growth in the last decade, therefore, textile producers are very keen to increase their exposure in the local retail market with the effort of producing good design and quality (Dawn 2016). Design perception is a very important external aspect to perceived good quality experience (Venkatesh et al 2012). Great experience of product usage increases the experiential value which increases satisfaction and improves consumer brand relationship (Mishra et al 2014).

Individual personality can influence the thinking of the consumer and effects experiential value (Hsiao 2017). Self-congruity theory suggests that people prefer to buy that apparel brand's product which is reflecting their ideal personality, because consumers have become more fashion conscious and want to keep themselves up to date with the latest fashion trends (Daveni 2010). Casidy (2012) suggests that fashion consciousness is strongly associated with personality traits, individuals who are open to experience are always ready to try new styles and fashion with excitement and want to project their social image to others through high involvement in apparel fashion shopping (Zhou et al 2010). The personality trait of openness to experience can increase the experiential value of an individual because they have a positive attitude towards pleasure and social values (Malykh 2017), so in this way their experiential value can be increased in a better way as compared to individuals with other personality traits.

\section{Literature review}

Design is the silent representative of any brand and design perception is the way of interpreting, understanding and thinking about the design of any product which is offered by any brand (Mishra et al 2015a; Homburg et al 2015). Design perception consists of three elements including aesthetics like social status and pleasure, functionality like core usability of the product and comfort design like ease of use of any product (Mishra 2016). Good design is a formation of meaningful usage experience and creation of customer end values (Venkatesh et al 2012). Design oriented strategy consists of two aspects, firstly it attempts provide a great consumption value to the customers and secondly the achievement of positive outcomes for the brand in the marketplace (Chen and Venkatesh 2013). Good product design is very important for strategic and 
competitive advantage with other competing brands in the marketplace and also very important to provide a good usage experience to generate experiential value for the customers (Jung et al 2014). Brand's designers can strengthen their brand's image by creating a positive design perception in the mind of the customers because product design is a key marketing tool to attain a competitive advantage and brand equity (Kumar and Noble 2016).

Value is the benefit that a customer receives from a product after it is purchased. Experiential value is the value that is derived from a satisfactory consumption experience with any product (Mishra et al 2015a). Experiential value is defined in literature as the usage pleasure and social value for the customer, usage pleasure includes fun, joy and happiness and social value includes social status, self-enhancement and self-esteem (Mishra 2016; Kumar and Noble 2016; Mishra et al 2015b, 2014). When the customer experiences the product with positive outcomes, it increases the experiential value of the customer (Varshneya et al 2017). Experiential value is the main point of the customer usage experience, if the product experience is positive, it helps the brand to build a strong consumer-brand relationship (Mishra et al 2014).

Social value and usage pleasure are the main elements of experiential value which come from usage experience of that particular product. It provides psychological benefits like self-identity and self-esteem (Sheng and Teo 2012). It is derived when products become a source of making impression on others and it helps consumers to show or increase their self-expression and status during the product consumption or experience (Mishra 2016). Pleasure in use defines as the aesthetic value which comes from product consumption, it comes inside from the user's feelings and includes attributes like fun, enjoy, satisfaction and excitement (Kumar and Noble 2016). It derives from usage pleasure experiential value when a customer wants to experience those products or services which are not only usable but also pleasurable (Sweeney and Soutar 2001).

Consumer based brand equity known as the name and symbol adds value which is connected with the brand (Lim and Weaver 2014). Brand equity is a set of brand assets and liabilities which is linked to a brand and the value provided by a product or service from a firm to their customers (Sun et al 2014). Nam et al (2011) suggest that various key elements for customer-based brand equity in service or apparel industries are staff behavior, physical quality, brand loyalty, brand identification, ideal self-congruence, brand satisfaction and lifestyle congruence (Buil et al 2013). Consumer based brand equity is a collective bundle of consumer perceptions, attitude, behavior and knowledge about any brand (Keller 1993). To achieve consumer-based brand equity, the brand should be developed using marketing strategies that focus more on long term relationship rather than one-time transaction (Pike 2012). Customers show a positive intention and good attitude towards a particular brand when they feel that that particular brand represents their lifestyle very well (Phau et al 2015). Consumer based brand equity provides benefits to the company, if the consumer-based brand equity is strong, it leads towards loyalty and brand preference, and the customer will be able to pay a premium price for that particular brand (Godey et al 2016). Brand equity theory says that consumer-based brand equity can be increased by creating a positive brand image in the mind of the 
Design perception and consumer-brand relationship...

customer (Keller 1993).

Openness to experience is one of the personality traits from the big five model of personality traits. Costa and McCrae (1992) discusses the big five model of personality traits which consists of conscientiousness, agreeableness, extraversion, neuroticism and openness to experience. Personality traits are defined as the personal tendencies, consistencies and modes of individual's adjustment according to his environment (He et al 2015). Individuals having openness to experience personality trait are those who usually appreciate art, passion, adventure, unusual ideas, interest, and variety of experience (Agyemang et al 2016). Moreover, individuals with high openness are said to pursue self-actualization specifically by seeking out intense, excited experiences and active participation in activities (Ismatullina and Voronin 2017). They are positive minded individuals and experience new things without any fear (Arora and Rangnekar 2016). They are ready to experience variety seeking behavior (Camperio Ciani et al 2007), and they can easily adapt and adjust in new environments. Figure 1 displays the conceptual model of this study.

Brands can strengthen customer-brand relationship through brand equity (Godey

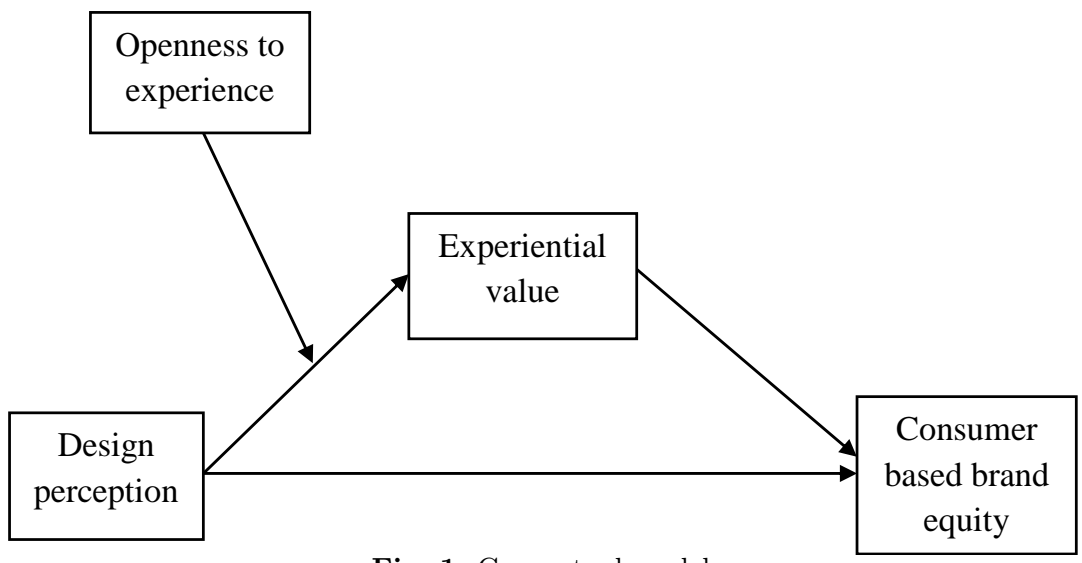

Fig. 1: Conceptual model

et al 2016) and brand equity can be achieved through providing good product design and consumption value to the customers (Mishra 2016). Design oriented strategies have two vital advantages, fulfilling the customer needs and demands and positive brand image and outcomes which leads towards consumer-based brand equity (Venkatesh et al 2012). Brands use product design as a strategy tool to strengthen the customer and brand relationship (Kumar and Noble 2016) to improve their brands worth and also get a competitive advantage in the market (Mishra et al 2014). If the product design is good and novel then brands can differentiate their brand from other brands and also make a positive impression on the customers (Jung et al 2014). This leads us to the following hypothesis:

Hypothesis 1 (H1):-There is a relationship between design perception and consumer based brand equity. 
R. Jibran et al.

Good brands always make those products which are not only good and novel in terms of their design but also provide a great usage experience to their customers (Mishra 2016). Good design can generate experiential value for the customers (Homburg et al 2015). Experiential value includes aspects like usability, social value, social status, self-image, self-accomplishment, self-esteem pleasure, happiness and comfort (Sheng and Teo 2012). Whenever customers interact with the product, they evaluate the product from the design and the quality of experience which they perceived (Gonzalez et al 2016). Product visual design (shape, design, style, color) can generate positive experiential value including social value like social status and usage pleasure value like fun and enjoyment for the customers (Mishra et al 2015a). Thus:

Hypothesis 2 (H2):-There is a relationship between design perception and experiential value.

When usage experience of the customer is positive with the particular brand, this will generate positive perceptions in the mind of the customer which increases the experiential value which leads towards brand equity (Park et al 2013). Experiential values like social value, pleasure in use and usability can generate consumer-based brand equity (Mishra et al 2015a), because these values increase when the customer has a satisfactory experience with the product and this will help to create a positive brand image and brand experience (Gonzalez et al 2016). Experiential value like social value and pleasure creates a positive brand image in the mind of the customer which takes the customer towards brand attachment, brand commitment, brand satisfaction, brand association and brand loyalty. Experiential value is the main point of the customer usage experience, if the product experience is positive, it helps the brand to build a strong consumer-brand relationship (Mishra et al 2014).This leads us to the following hypothesis:

Hypothesis 3 (H3):- There is a relationship between experiential value and consumer based brand equity.

Product design perception and experiential value has a significant impact on consumer-based brand equity (Mishra 2016). Experiential value plays a very important role as a mediator between the relationship of design perception and consumer-based brand equity (Mishra et al 2015a). Product design is the first point of interaction between the customer and the product. Product design can generate a lot of benefits like social value including social status, selfaccomplishment and usage pleasure like joy and happiness for the user to make a quality usage experience (Mishra et al 2014), and this meaningful consumption experience creates a positive brand image and brand association in the mind of the customer, which are important components of customer based brand equity (Huang et al 2014). Those organizations that employ the design thinking philosophy have been successful in the market because benefits through implementation of design strategy fulfill the customer need, making their consumption experience fruitful which leads toward strong customer-brand relationship (Chen and Venkatesh 2013). This leads us to the following hypothesis:

Hypothesis 4 (H4):-Experiential value mediates the relationship between design perception and consumer based brand equity.

People with the personality trait of openness to experience like to experi- 
ence new things without any fear because they have a variety seeking behavior (Malykh 2017). Those individuals are always tending to deal with variety of experiences for their own sake (Arora and Rangnekar 2016). Research suggests that those individuals who have personality trait of openness to experience have more positive response towards experiential value including pleasure and social values like fun and social status because they like to experience new things and express themselves without any hesitation (Karl et al 2007). Openness to experience is a moderating variable that can increase the experiential value of the customer because openness to experience personality trait encompasses the positive attitude towards usage pleasure and social experiential values as compared to other traits. This leads us to the following hypothesis:

Hypothesis 5 (H5):-Openness to experience moderates the relationship between design perception and experiential value.

The contribution of this paper on the theoretical side is significant, as it highlights the new area in marketing domain i.e design perception. Means-end theory suggests that good product design helps customers to attain consumption value (Graeff 1997). Design value theory by Noble and Kumar (2010) provides significant contribution for developing the framework for design perception. The theory of brand experience by Brakus et al (2009) describes that feelings and emotions is a major force in consumer-brand interaction in an experiential setting. This work relates with consumption value theory (Holbrook 1999) and brand equity theory (Keller 1993) to develop a novel model of product design and experience derived consumer based brand equity.

\section{Research methodology}

\subsection{Population and sample}

Population for this study includes the consumers of textile apparel industry of Pakistan. The target population involves all urban, educated, middle class male and female customers, between the age twenty to forty five, living in metropolitan cities of Pakistan. Sample of this study was taken from different cities of Pakistan. Sample size was 210.

\subsection{Data collection}

Data was collected through self-administrated questionnaires. Questionnaires were floated to the respondents by using convenience sampling technique. Mall intercept technique was used for this study. Data was collected from the customers of apparel brands from brand's outlets where people came for shopping. Total 250 questionnaires were floated to respondents. 225 questionnaires were received back, so the response rate was $90 \%$. 15 questionnaires were discarded due to incomplete information. The sample size used for further analysis was 210 .

Business Review: (2020) 15(2):86-100 
R. Jibran et al.

\subsection{Measures}

The measurement of all the constructs in this research was done by using empirically well-established scales. In this study 5-point Likert scale ranging from 1 "Strongly disagree" to 5 "Strongly agree" was used. The questionnaire was constructed on the measures of design perception, experiential value, openness to experience personality trait and consumer based brand equity.

For measuring design perception, 5 items scale was adopted, developed by Mishra (2016). Other items were excluded from this study because those items were applicable just for digital devices not for apparel, so those items were excluded. Reported reliability of this measure was 0.7 (Mishra 2016). For measuring experiential value, nine items scale was used, adopted from Sweeney and Soutar (2001) as used by Mishra (2016). Reported reliability of this measure was 0.92 (Mishra et al 2015a). For measuring Openness to experience, 10 items scale including 2 reverse coded items adopted from John et al (1999) was used. Standard procedure was adopted for reverse coded items before analysis. Reported reliability of this measure was 0.77 (Selvarajanet al., 2016). 23 items of consumer based brand equity were adopted from Çifci et al (2016). Reported reliability of this measure was 0.86 (Çifci et al 2016).

\section{Results}

4.1 Validity analysis

Construct validity was used for validity analysis. It measures the quality of an instrument.

\subsubsection{Convergent validity:}

Table 1 shows the convergent validity analysis. Fornell and Larcker (1981) suggest that if AVE is less than 0.5, but composite reliability is higher than 0.6, the convergent validity of the construct is still acceptable. Composite reliability of all constructs is greater than 0.6 which means that convergent validity is acceptable.

Table 1: Convergent validity analysis

\begin{tabular}{lcc}
\hline Constructs & AVE & CR \\
\hline Design perception & 0.51 & 0.83 \\
Experiential value & 0.33 & 0.78 \\
Consumer based brand equity & 0.26 & 0.82 \\
Openness to experience & 0.33 & 0.75 \\
\hline
\end{tabular}


Design perception and consumer-brand relationship...

\subsubsection{Discriminant validity}

Table 2 shows the results of discriminant validity. Results show that squared correlation values are less than AVE and Bontis and Serenko (2007) condition is also satisfied, which confirms the discriminant validity at construct level.

Table 2: Discriminant validity analysis

\begin{tabular}{|c|c|c|c|c|}
\hline \multicolumn{5}{|c|}{ Correlations matrix } \\
\hline & $\begin{array}{l}\text { Design per- } \\
\text { ception }\end{array}$ & $\begin{array}{l}\text { Experiential } \\
\text { value }\end{array}$ & $\begin{array}{l}\text { Consumer } \\
\text { based brand } \\
\text { equity }\end{array}$ & $\begin{array}{l}\text { Openness to } \\
\text { experience }\end{array}$ \\
\hline Design perception & 0.678 & & & \\
\hline Experiential value & 0.186 & 0.683 & & \\
\hline Consumer based brand equity & 0.025 & 0.486 & 0.411 & \\
\hline Openness to experience & 0.016 & 0.052 & 0.025 & 0.458 \\
\hline
\end{tabular}

4.2 Fitness of evaluating model

Table 3 shows the result of SEM model fit. Results suggest that P-value is 0.091 $(\mathrm{P}>0.05)$. RMSEA value is $0.04(<0.08)$. GFI value is $0.960(>0.90)$. AGFI value is $0.915(>0.90)$. CFI value is $0.979(>0.90)$. TLI value is $0.964(>0.90)$. NFI value is $.932(>0.90)$. Chi-square / DF value is 1.38 (> 3.0). All results are good, so it means that the model which is used for this research is fit.

Table 3: Model fit analysis

\begin{tabular}{llc}
\hline Name of category & Name of index & Results \\
\hline 1. Absolute fit & P & 0.091 \\
& RMSEA & 0.048 \\
& GFI & 0.960 \\
\hline 2. Incremental fit & AGFI & 0.915 \\
& CFI & 0.979 \\
& TLI & 0.964 \\
& NFI & 0.932 \\
\hline 3. Parsimonious fit & Chi-square & 1.380 \\
\hline
\end{tabular}

\subsection{Correlation}

Table 4 shows the correlation results among variables. The correlation between design perception and consumer based brand equity is $0.47(\mathrm{P}=0.00)$ which shows positive and strong association between design perception and consumer based brand equity. This result suggests that first hypothesis (H1) is accepted. The correlation between design perception and experiential value is $0.50(\mathrm{P}=$

Business Review: (2020) 15(2):86-100 
R. Jibran et al.

0.00) which indicates positive and strong relationship between design perception and experiential value. This result suggests that second hypothesis (H2) is accepted. The correlation between experiential value and consumer based brand equity is $0.68(\mathrm{P}=0.00)$ which indicates that there is positive and strong relationship between experiential value and consumer based brand equity. This result suggests that third hypothesis (H3) is also accepted.

Table 4: Correlation analysis

\begin{tabular}{lrrrrrc}
\hline \multicolumn{1}{c}{ Table 4: Correlation analysis } \\
\hline & Mean & SD & 1 & 2 & 3 & 4 \\
1- Openness to experience & 3.64 & 0.32 & 0.78 & & & \\
2- Design Perception & 3.94 & 0.31 & $.15^{* *}$ & 0.81 & & \\
3- Experiential value & 4.04 & 0.29 & 0.10 & $0.50^{* *}$ & 0.79 & \\
4- Consumer based brand equity & 4.08 & 0.27 & 0.01 & $0.47^{* *}$ & $0.68^{* *}$ & 0.85 \\
\hline
\end{tabular}

4.4 Simple linear regression

\subsubsection{Design perception and consumer based brand equity}

Simple linear regression results are shown in table 5 . Results shows that $R^{2}$ value is $0.22(\mathrm{P}=0.000)$ between the relationships of design perception and consumer based brand equity, which suggests that $22 \%$ variance in the consumer-based brand equity is due to design perception. Between the relationship of design perception and experiential value, $R^{2}$ value is $0.25(\mathrm{P}=.000)$ which suggests that $25 \%$ variance in the experiential value is due to design perception. Furthermore, results shows that $R^{2}$ value is $0.47(\mathrm{P}=0.000)$ between the relationships of experiential value and consumer based brand equity, which suggest that $47 \%$ variance in the consumer-based brand equity is due to experiential value.

Table 5: Regression analysis

\begin{tabular}{lccc}
\hline Relationships & $R^{2}$ & $\beta$ & $\mathrm{P}$ \\
\hline Design perception and consumer based brand equity & 0.220 & 0.470 & 0.000 \\
Design perception and experiential value & 0.250 & 0.500 & 0.000 \\
Experiential value and consumer-based brand equity & 0.470 & 0.680 & 0.000 \\
\hline
\end{tabular}

\subsection{Mediation analysis}

For mediation analysis, statistical software AMOS has been used. In table 6, results describe that indirect effect value is 0.30 and $\mathrm{P}$ value is $0.001(\mathrm{P}<0.05)$ which suggests that the mediator plays a significant role in this conceptual framework. Value of total effect is 0.47 which describes that $47 \%$ variation is projected in consumer-based brand equity because of design perception and the mediator experiential value. 
Design perception and consumer-brand relationship...

\begin{tabular}{lcc}
\multicolumn{3}{c}{ Table 6: Mediation analysis } \\
\hline Effects & $R^{2}$ & $\mathrm{P}$ \\
\hline Total effect & 0.470 & 0.001 \\
Direct effect & 0.170 & 0.000 \\
Indirect effect & 0.300 & 0.001 \\
\hline
\end{tabular}

According to Preacher and Hayes (2008) when the mediator is run between independent variable and dependent variable, if the relationship of the independent and dependent variable turns into an insignificant relationship it means that there is full mediation and if the relationship of independent and dependent variable is still significant it means that there is partial mediation. Table 7 shows the significance level of all the relationships of this model. Result shows that after the mediation test the relationship of design perception and consumer based brand equity is still significant with the $\mathrm{P}$ value of $0.005(\mathrm{P}<0.05)$, which shows partial mediation.

Table 7: Regression weights

\begin{tabular}{llllc}
\hline Relationships & & S.E. & C.R. & P Label \\
\hline $\begin{array}{l}\text { Experiential value } \leftarrow \text { Design } \\
\text { perception }\end{array}$ & 0.062 & 7.599 & $* * *$ \\
$\begin{array}{l}\text { Consumer based brand equity } \\
\leftarrow \text { Experiential value }\end{array}$ & 0.06 & 9.394 & $* * *$ \\
$\begin{array}{l}\text { Consumer based brand equity } \\
\leftarrow \text { Design perception }\end{array}$ & 0.056 & 2.792 & 0.005 \\
\hline
\end{tabular}

\subsection{Moderation test}

Moderating test (table 8) shows that the moderating effect of openness to experience on the relationship between design perception and experiential value is statistically significant. Hence, H5 stands accepted.

For better understanding of moderation analysis, the moderation graph is

Table 8: Regression weights

\begin{tabular}{lcccc}
\hline & Estimate & S.E. & C.R. & P Label \\
\hline Experiential value $\leftarrow$ Design perception & 2.646 & 0.662 & 3.994 & $* * *$ \\
$\begin{array}{l}\text { Experiential value } \leftarrow \text { Openness to experi- } \\
\text { ence }\end{array}$ & 2.309 & 0.761 & 3.034 & 0.002 \\
Experiential value $\leftarrow$ Interactive term & 1.893 & 0.588 & 3.217 & 0.001 \\
\hline
\end{tabular}

shown in figure 2. Figure 2 suggests that when the individual scores high in openness to experience personality trait, his design perception will be high and when the design perception of openness individuals is high then his experiential 
R. Jibran et al.

value will increase, which clearly suggests that openness to experience personality trait has a significant moderating effect on the relationship between design perception and experiential value.

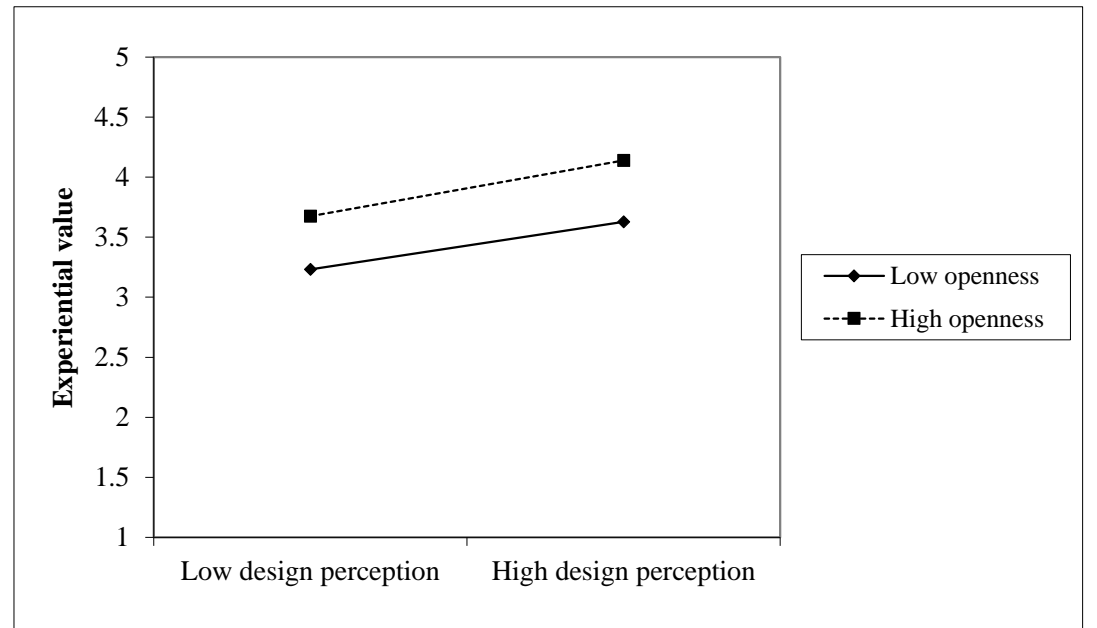

Fig. 2: Moderating effect of openness to experience on the relationship between design perception and experiential value

\section{Discussion}

This study investigates the relationship of design perception and consumerbased brand equity. As per the previous findings design perception has a significant impact on consumer-based brand equity (Mishra 2016; Mishra et al 2015a, 2014), which is also found in this study. In this research direct relationship between design perception and consumer-based brand equity is significant which indicates design perception has a significant impact on consumer-based brand equity.

Whenever customers interact with the product, they evaluate the product from the design and the quality of experience which they perceive (Homburg et al 2015). If the interaction is positive with the design of the product this will lead towards satisfied experience which will provide greater experiential value (Gonzalez et al 2016). In this study the relationship of design perception and experiential value is also significant which suggests that design perception increases experiential value for the customers. For example, if the product design perception is good in the mind of the customers then consumption experience will be positive for the customers (Brakus et al 2009). These positive experiences with the product enhance the usage pleasure and social value for the customers (Kumar and Noble 2016). Usage pleasure values consist of pleasure, joy, happiness and amusement; social values consist of social status, self-esteem and self-enhancement (Mishra 2016). Relationship between experiential value and 
consumer-based brand equity is also significant in this study which indicates that good experience value helps to strengthen consumer-brand relationship because positive experience and perceived values can be major source of effective consumer-brand relationship (Park et al 2013).

This study also investigates the influence of openness to experience personality trait on the relationship between design perception and experiential value. Openness to experience individuals like to play with unusual ideas and they prefer to experience new things without any hesitation (Agyemang et al 2016). Different researchers suggest that those people who have personality trait of openness to experience have more positive response towards new experiences which can help them to increase their experiential value (Ismatullina and Voronin 2017). Result shows that openness to experience personality trait has a significant moderating effect on the relationship between design perception and experiential value. Individuals who score high in openness to experience personality trait; have higher design perception; when design perception of openness individual is high then their experiential value will increase.

\section{Managerial implications}

This research framework offers guidelines for marketers and managers. Findings suggest that managers should use design strategy to build strong consumerbrand relationship. Product design is a critical factor for brand success. Managers should know how the product-brand domain works, they should be able to make those designs which are according to the customer needs to build positive design perception in the mind of the customers. This framework will help managers to increase their brand values through producing effective product designs. Designers have to know that only functional usability of the products is not enough to create strong consumer-brand relationship. Designers have to design the products in a way that can ensure pleasure and social experiential value for the consumers from the consumption experience. To make this happen they have to design products that are elegant and eye catching, the clothes have to be visually appealing which helps customers to increase pleasure and social status in front of their social group.

Individuals with the personality trait openness to experience are those individuals who are always ready to experience new things as compared to other individuals. So in this case marketers and managers should make profiles of that kind of potential individuals and position them separately with respect to designs.

\section{Limitations and future research}

This research work has several limitations. It focuses on the relationship of design perception and consumer based brand equity through experiential value. One of the key limitations is the generalizability of the data and results because convenience sampling was used in this study which limits the potential of generalizability of the findings, because through convenience sampling the 
R. Jibran et al.

sample and conclusion is not representative of the whole population. In future research work other sampling techniques can be used to make the results more generalizable.

This conceptual framework is well established in the product context but applicability of this framework in the service domain can face some difficulties. For making this framework adaptable in the service context, empirical validation needs to be done. This study is conducted on the textile apparel sector. In this case other industries were excluded. For future studies other industries of Pakistan can be used. This research uses cross sectional research design due to resource constraints, for future research longitudinal research design can be used to measure change. Future research studies can use price as moderator between design perception and experiential value. Products with superior or luxury look with low and affordable prices can result in different personal and social experience for the user which can increase their experiential values as well. This can be a potential and favorable area of exploration in future studies.

\section{Conclusion}

This study is conducted in the textile apparel industry to see how design perception increases or decreases the consumer-brand relationship through pleasure and social consumption experience which is known as experiential value. We find that positive design perception generates meaningful consumption experience for the user which increases experiential value and leads towards a strengthened consumer-brand relationship which is known as consumer-based brand equity. Our findings suggest that positive design perception has a significant impact on user experience. This framework and findings suggest that user experience is the key source of quality consumer and brand relationship.

The findings also show that openness to experience personality has a moderating effect on the relationship between design perception and experiential value. Our theory represents the novel contribution in this literature with two diverse fields of research: one is design and other is brand equity. Our framework also represents the modern concept of design thinking philosophy which combines the design and marketing outcomes together. As designers we have to be focused on customers and meaningful user experience is the key source of success in the marketplace. Brands have to make products with effective design to achieve competitive advantage. It is important that designers not only fulfill the customer needs through effect usability of the product but they have to make those designs that thrill the customers with pleasure and social value. Designers have to consider two things: one is consumer perception of the design and second is the impact of the design on user experience and consumer brand relationship. Means and chain theory is the best example of how good design derives the meaningful user consumption experience and how experiential value leads towards consumer-based brand equity. Hence, there is clear need for brands to adopt design thinking strategy while putting design and marketing efforts together to fulfill the customer needs and provide positive usage experience to strengthen consumer-brand association. 
Design perception and consumer-brand relationship...

\section{References}

Agyemang FG, Dzandu MD, Boateng H (2016) Knowledge sharing among teachers: the role of the big five personality traits. VINE Journal of Information and Knowledge Management Systems

Arora R, Rangnekar S (2016) Dispositional traits influence on mentoring relationships. South Asian Journal of Global Business Research

Bontis N, Serenko A (2007) The moderating role of human capital management practices on employee capabilities. Journal of knowledge management

Brakus JJ, Schmitt BH, Zarantonello L (2009) Brand experience: what is it? how is it measured? does it affect loyalty? Journal of marketing 73(3):52-68

Brakus JJ, Schmitt BH, Zhang S (2014) Experiential product attributes and preferences for new products: The role of processing fluency. Journal of Business Research 67(11):22912298

Buil I, Martínez E, De Chernatony L (2013) The influence of brand equity on consumer responses. Journal of consumer marketing

Camperio Ciani AS, Capiluppi C, Veronese A, Sartori G (2007) The adaptive value of personality differences revealed by small island population dynamics. European Journal of Personality: Published for the European Association of Personality Psychology 21(1):3-22

Casidy R (2012) An empirical investigation of the relationship between personality traits, prestige sensitivity, and fashion consciousness of generation y in australia. Australasian Marketing Journal (AMJ) 20(4):242-249

Chen S, Venkatesh A (2013) An investigation of how design-oriented organisations implement design thinking. Journal of Marketing Management 29(15-16):1680-1700

Cifci S, Ekinci Y, Whyatt G, Japutra A, Molinillo S, Siala H (2016) A cross validation of consumer-based brand equity models: Driving customer equity in retail brands. Journal of Business Research 69(9):3740-3747

Costa PT, McCrae RR (1992) Neo personality inventory-revised (NEO PI-R). Psychological Assessment Resources Odessa, FL

Daveni R (2010) Fashion conscious: Lessons in commoditization from the fashion industry. Ivey Business Journal 74(2):1-4

Dawn (2016) Retrieved from may 23, 2016, from https://www.dawn.com/news/1260022

Dawn (2017) Retrieved from march 20, 2017, from https://www.dawn.com/news/1321673.

Fornell C, Larcker DF (1981) Structural equation models with unobservable variables and measurement error: Algebra and statistics

Godey B, Manthiou A, Pederzoli D, Rokka J, Aiello G, Donvito R, Singh R (2016) Social media marketing efforts of luxury brands: Influence on brand equity and consumer behavior. Journal of business research 69(12):5833-5841

Gonzalez I, Val E, Justel D, Iriarte I (2016) Closing the brand gap through innovation and design. Procedia CIRP 50(1):112-116

Graeff TR (1997) Comprehending product attributes and benefits: The role of product knowledge and means-end chain inferences. Psychology \& Marketing 14(2):163-183

He H, Wang W, Zhu W, Harris L (2015) Service workers job performance. European Journal of Marketing

Holbrook MB (1999) Consumer value: a framework for analysis and research. Psychology Press

Homburg C, Schwemmle M, Kuehnl C (2015) New product design: Concept, measurement, and consequences. Journal of marketing 79(3):41-56

Hsiao KL (2017) Compulsive mobile application usage and technostress: the role of personality traits. Online Information Review

Huang JL, Ryan AM, Zabel KL, Palmer A (2014) Personality and adaptive performance at work: A meta-analytic investigation. Journal of Applied Psychology 99(1):162

Ismatullina V, Voronin I (2017) Gender differences in the relationships between big five personality traits and intelligence. Procedia-Social and Behavioral Sciences 237:638-642

John OP, Srivastava S, et al (1999) The big five trait taxonomy: History, measurement, and theoretical perspectives. Handbook of personality: Theory and research 2(1999):102-138

Jung HS, Kim KH, Lee CH (2014) Influences of perceived product innovation upon usage behavior for mmorpg: Product capability, technology capability, and user centered design. Journal of Business Research 67(10):2171-2178

Business Review: (2020) 15(2):86-100 
R. Jibran et al.

Karl KA, Peluchette JV, Harland L (2007) Is fun for everyone? personality differences in healthcare providers'attitudes toward fun. Journal of health and human services administration pp 409-447

Keller KL (1993) Conceptualizing, measuring, and managing customer-based brand equity. Journal of marketing 57(1):1-22

Kumar M, Noble CH (2016) Beyond form and function: Why do consumers value product design? Journal of Business Research 69(2):613-620

Lim Y, Weaver PA (2014) Customer-based brand equity for a destination: The effect of destination image on preference for products associated with a destination brand. International Journal of Tourism Research 16(3):223-231

Malykh S (2017) The role of personality traits and intelligence in academic achievement of russian high school students. Procedia-Social and Behavioral Sciences 237:1304-1309

Mishra A (2016) Attribute-based design perceptions and consumer-brand relationship: Role of user expertise. Journal of Business Research 69(12):5983-5992

Mishra A, Dash SB, Cyr D (2014) Linking user experience and consumer-based brand equity: the moderating role of consumer expertise and lifestyle. Journal of Product \& Brand Management

Mishra A, Dash S, Malhotra N, Cyr D (2015a) Measuring consumer design perceptions for digital devices: A multi-dimensional scale. Journal of Brand Management 22(7):603-630

Mishra A, Dash S, Malhotra NK (2015b) An integrated framework for design perception and brand equity. Ams Review 5(1-2):28-44

Nam J, Ekinci Y, Whyatt G (2011) Brand equity, brand loyalty and consumer satisfaction. Annals of tourism Research 38(3):1009-1030

Noble CH, Kumar M (2010) Exploring the appeal of product design: A grounded, valuebased model of key design elements and relationships. Journal of Product Innovation Management 27(5):640-657

Park H, Lim H, Kim YK (2013) Experiential value: Application to innovative consumer technology products. Journal of Customer Behaviour 12(1):7-24

Phau I, Teah M, Lim A, Ho R (2015) A brief affair with underwear: Uniqueness and innovativeness in male underwear brand purchases. Journal of Global Fashion Marketing $6(3): 222-235$

Pike S (2012) Destination positioning opportunities using personal values: Elicited through the repertory test with laddering analysis. Tourism management 33(1):100-107

Preacher KJ, Hayes AF (2008) Asymptotic and resampling strategies for assessing and comparing indirect effects in multiple mediator models. Behavior research methods 40(3):879-891

Sheng ML, Teo TS (2012) Product attributes and brand equity in the mobile domain: The mediating role of customer experience. International journal of information management 32(2):139-146

Sun Y, Kim KH, Kim J (2014) Examining relationships among sustainable orientation, perceived sustainable marketing performance, and customer equity in fast fashion industry. Journal of Global Fashion Marketing 5(1):74-86

Sweeney JC, Soutar GN (2001) Consumer perceived value: The development of a multiple item scale. Journal of retailing $77(2): 203-220$

Varshneya G, Das G, Khare A (2017) Experiential value: a review and future research directions. Marketing Intelligence \& Planning

Venkatesh V, Thong JY, Xu X (2012) Consumer acceptance and use of information technology: extending the unified theory of acceptance and use of technology. MIS quarterly pp 157178

Zhou JX, Arnold MJ, Pereira A, Yu J (2010) Chinese consumer decision-making styles: A comparison between the coastal and inland regions. Journal of Business Research 63(1):4551 